\title{
Sources of reducing equivalents for nitrate reductase in Pisum arvense roots
}

\section{GRAZYNA KŁOBUS}

\author{
Department of Plant Physiology, Institute of Botany, \\ Wrocław University, Kanonia 6/8, 50-328 Wrocław, Poland \\ (Received: November 30, 1983. Revision accepted: May 10, 1984)
}

\begin{abstract}
The sources of the nitrate reductase (E.C 1.6.6.1) reducing equivalents were searched for in roots of Pisum arvense by measuring in vivo and in vitro nitrate reductase activity. It was found that the $\mathrm{NADH}_{2}$ utilised in the process of nitrate reduction in the roots of $P$. arvense may be formed by glycolysis as well as in processes of organic acids oxidation such as 2-oxoglutaric, succinic and malic acids.
\end{abstract}

Key words: nitrate reductase, reducing equivalents, Pisum arvense, roots

\section{INTRODUCTION}

The activity of nitrate reductase, the first enzyme on the nitrate reduction pathawy, is specifically dependent on $\mathrm{NADH}_{2}$ as electron donor ( $\mathrm{B}$ e e vers and $\mathrm{H}$ a ge $\mathrm{m}$ a $\mathrm{n} 1969, \mathrm{H}$ e w it t 1975). According to the investigations of $\mathrm{Klepper}$ et al. (1971). $\mathrm{NADH}_{2}$ utilised during nitrate reduction is produced in the process of glycolysis as the result of oxidation of triose phosphates. Lips (1971) claimed that one of main sources of nitrate reductase reductors in green tissues is the reaction catalysed by glycolate dehydrogenase. Similar suggestions were advanced by Plaut and Litton (1974). Neyra and $\mathrm{H}$ agema $\mathrm{n}$ (1978) demonstrated that $\mathrm{NADH}_{2}$ for nitrate reduction in maize leaves (plants of type C-4) is probably formed by oxidation of malate produced during photosynthesis. Similarly M a n et al. (1978), and also earlier M u lde r et al. (1959) ascertained that in spinach leaves (plants of type C-3) oxidation of malate or isocitrate may supply $\mathrm{NADH}_{2}$ for nitrate

Abbreviations used: $\mathrm{NR}$ - nitrate reductase, $\mathrm{MDH}$ - malate dehydrogenase. 
reduction. All the above quoted papers concerned green tissues. It is known, however, that nitrate reduction occurs as well in roots ( $\mathrm{S}$ a $\mathrm{n}$ derson and Cocking 1964, B uczek 1976). $\mathrm{NADH}_{2}$ utilised in the nitrate reduction is also produced in roots. However, apart from two communications of Dea n e-Drum on nd et al. (1979, 1980) suggesting the participation of malate dyhdrogenase in production of reduction power for NR activity in barley roots, data are lacking as regards the sources of reducing equivalents for the activity of this enzyme in roots. In view of this situation the present investigations were undertaken with the purpose of establishing the main metabolic pathways which might potentially lead to $\mathrm{NADH}_{2}$ formation for nitrate reductase. As model plant Pisum arvense was chosen.

\section{MATERIAL AND METHODS}

The experiments were performed on roots of Pisum arvense L. cultivated in hydroponic cultures. The seeds were germinated for three days in darkness at $27^{\circ} \mathrm{C}$. Equal-sized seedlings were transferred to glass crystallisers, covered with aluminium foil and filled with preliminary nutrient medium deprived of nitrogen and containing the following components, in $\mu$ moles: $\mathrm{K}_{2} \mathrm{SO}_{4}-3.0, \mathrm{CaH}_{2} \mathrm{PO}_{4} \cdot \mathrm{H}_{2} \mathrm{O}-1.0, \mathrm{MgSO}_{4} \cdot 7 \mathrm{H}_{2} \mathrm{O}-$ 1.0 and $\mathrm{Fe}$-citrate -0.017 . One cu. $\mathrm{cm}$ of microelements was added to the medium (0.021 mg $\mathrm{H}_{3} \mathrm{BO}_{3}, 0.241 \mathrm{mg} \mathrm{MnSO}_{4} \cdot 5 \mathrm{H}_{2} \mathrm{O}, 0.025 \mathrm{mg} \mathrm{CuSO} \cdot 5 \mathrm{H}_{2} \mathrm{O}$, $0.025 \mathrm{mg} \mathrm{ZnSO} \mathrm{Zn}_{4} \cdot 7 \mathrm{H}_{2} \mathrm{O}, 0.0024 \mathrm{mg} \mathrm{CoSO}{ }_{4} \cdot 7 \mathrm{H}_{2} \mathrm{O}, 0.012 \mathrm{mg} \mathrm{Na} \mathrm{MoO}_{4} \cdot 2 \mathrm{H}_{2} \mathrm{O}$ ) and the plants were placed in a glasshouse. After three days of growth the remains of seeds were removed and the seedlings were transferred to $500 \mathrm{~cm}^{3}$ beakers filled with Hoagland's medium consisting of $\left(\mathrm{mmoles} \cdot \mathrm{dm}^{-3}\right): \mathrm{Ca}\left(\mathrm{NO}_{3}\right)_{2}-5, \mathrm{KNO}_{3}-5, \quad \mathrm{KH}_{2} \mathrm{PO}_{4}-1$ with microelements added as specified above. $\mathrm{pH}$ of both media was adjusted to 6.5.

Nitrate reductase activity (in vitro). Roots of 9-day $P$. arvense seedlings were used for analysis. Enzymic extracts were prepared in $0.05 \mathrm{M}$ Tris- $\mathrm{HCl}$ buffer ( $\mathrm{pH} 7.8$ ) containing $5 \mathrm{mM}$ cystein and $2.5 \mathrm{mM}$ EDTA. NR activity was determined by the method of $\mathrm{H}$ a ge m a n and F lesher (1960). The reaction mixture contained $100 \mu$ moles phosphate buffer, $\mathrm{pH} 7.5,20 \mu$ moles $\mathrm{KNO}_{3}, 0.7 \mu$ mole $\mathrm{NADH}_{2}$ and $0.2 \mathrm{~cm}^{3}$ enzymic extract. The total volume of the mixture was $2 \mathrm{~cm}^{3}$. After incubating the samples for $30 \mathrm{~min}$ at $27^{\circ} \mathrm{C}$ the reaction was stopped by addition of $0.5 \mathrm{~cm}^{3}$ of $30 \mathrm{mM}$ zinc acetate solution. The precipitate was centrifuged off for $10 \mathrm{~min}$ at $20000 \times \mathrm{g}$ and the amount of nitrites formed during the reaction was determined colorimetrically (H a r per and $\mathrm{H}$ a g e $\mathrm{m}$ a $\mathrm{n}$ 1972) in the supernatant.

Nitrate reductase activity (in vivo) was measured by the method described by $\mathrm{J}$ aworski (1971). Roots of the 9-old day of P. arvense 
were placed in Erlenmayer flasks containing $500 \mu$ moles of $\mathrm{K}$-phosphate buffer ( $\mathrm{pH}$ 7.5), $10 \mu$ moles $\mathrm{KNO}_{3}$ and 1 per cent 1-propanol. Total volume of incubation medium was $5 \mathrm{~cm}^{3}$. The samples were incubated for $1 \mathrm{hr}$ in darkness, at $30^{\circ} \mathrm{C}$ and the amount of nitrite produced was determined ( $\mathrm{H}$ arper and $\mathrm{H}$ a g e m a $\mathrm{n} 1972$ ).

\section{RESULTS}

The data shown in Table 1 indicate that $\mathrm{NADPH}_{2}$, in contrast to $\mathrm{NADH}_{2}$, is not an effective electron donor for nitrate reductase in $P$. arvense roots. Addition of sugar phophates into the incubation medium distinctly stimulated NR in vivo, the increase of activity being highest in the presence of fructose-1,6-diphosphate. Organic acids such as malic, 2 -oxoglutaric and succinic acid present in the incubation medium containing also $\mathrm{NAD}^{+}$or $\mathrm{FAD}^{+}$did not affect $\mathrm{NR}$ activity.

\section{Table 1}

Influence of various substrates $(25 \mu \mathrm{M})$ added to the incubation medium on nitrate reductase activity in vivo in Pisun arvense roots

\begin{tabular}{|c|c|c|}
\hline \multirow{2}{*}{ Substrate } & \multicolumn{2}{|c|}{ Nitrate reductase activity } \\
\hline & nmole $\mathrm{NO}_{2} \cdot \mathrm{g}^{-1}$ fr. wt. $\cdot \mathrm{h}^{-1}$ & $\%$ \\
\hline Control* & $758.1 \pm 23.4$ & 100 \\
\hline ATP & $745.5 \pm 21.8$ & 98 \\
\hline NAD * & $732.2 \pm 21.3$ & 96 \\
\hline $\mathrm{NADPH}_{2}$ & $601.2 \pm 24.5$ & 79 \\
\hline $\mathrm{NADH}_{2}$ & $951.1 \pm 34.2$ & 125 \\
\hline Glucose-6-phosphate $+\mathrm{NAD}^{*}+\mathrm{ATP}$ & $1824.6 \pm 63.7$ & 225 \\
\hline Fructose-6-phosphate $+\mathrm{NAD}^{+}+\mathrm{ATP}$ & $1814.6 \pm 60.8$ & 239 \\
\hline Fructose-1,6-diphosphate $+\mathrm{NAD}^{+}+\mathrm{ATP}$ & $2113.4 \pm 69.1$ & 279 \\
\hline Malic acid $+\mathrm{NAD}^{+}$ & $524.1 \pm 20.2$ & 69 \\
\hline 2-oxoglutaric acid + NAD $^{+}$ & $642.3 \pm 20.7$ & 85 \\
\hline Succinic acid +FAD & $640.0 \pm 21.4$ & 85 \\
\hline
\end{tabular}

* The samples contained phosphate buffer, propanol and $\mathrm{KNO}_{3}$ in concentrations given in Material and methods. The results are means of five replications. The differences between arithmetic means of two different combinations exceeding two times the $\mathrm{SE}$ value are considered as significant.

The influence of the tested organic acids on NR activity became pronounced if the $P$. arvense roots, before being placed in the incubation medium were preincubated for $2 \mathrm{~h}$ in a solution of these acids in the presence of $\mathrm{NAD}^{+}$or $\mathrm{FAD}^{+}$(Table 2). Root preincubation, however, in a buffer with organic acids but without $\mathrm{NAD}^{+}$or $\mathrm{FAD}^{+}$did not produce significant changes in NR activity. It was found at the same time that addition of malonic acid to the incubation medium inhibited completely 
NR activity and depressed the stimulating effect of succinic acid and 2-oxoglutaric acid on the enzyme activity. In the presence of malonic acid NR activation by malic acid and $\mathrm{NAD}^{+}$was also weaker.

Table 2

In vivo activity of nitrate reductase of Pisum arvense roots preincubated for $2 \mathrm{~h}$ in $25 \mathrm{mM}$ solution of organic acids

\begin{tabular}{|l|c|}
\hline \multicolumn{1}{|c|}{ Substrates } & $\begin{array}{c}\text { Nitrate reductase activity, } \\
\text { nmoles } \mathrm{NO}_{2}^{-} \cdot \mathrm{g}^{-1} \mathrm{fr} . \mathrm{wt}^{\circ} \mathrm{h}^{-1}\end{array}$ \\
\hline Control & \\
Malonic acid & $266.40 \pm 9.2$ \\
Malic acid & $18.60 \pm 0.6$ \\
Malic acid $+\mathrm{NAD}^{+}$ & $254.63 \pm 10.0$ \\
Malic acid $+\mathrm{NAD}^{*}+$ malonic acid & $780.55 \pm 23.1$ \\
Succinic acid & $495.05 \pm 17.6$ \\
Succinic acid $+\mathrm{FAD}^{+}$ & $270.09 \pm 8.3$ \\
Succinic acid $+\mathrm{FAD}^{+}+$malonic acid & $602.06 \pm 21.8$ \\
2-oxoglutaric acid & $233.20 \pm 7.9$ \\
2-oxoglutaric acid $+\mathrm{NAD}^{*}$ & $248.09 \pm 8.3$ \\
2-oxoglutaric acid $+\mathrm{NAD}^{*}+$ malonic acid & $959.04 \pm 27.4$ \\
\hline
\end{tabular}

* Control samples contained phosphate buffer, propanol and $\mathrm{KNO}_{3}$ in concentrations mentioned in Material and methods. The roots cut from the plants were preincubated for $2 \mathrm{~h}$ in solutions of the substances mentioned in the table. After careful washing the roots were used to determination of nitrate reductase activity in vivo (see Material and methods). The results are means of five replications.

Changes in NR activity in $P$. arvense roots after preliminary 2-h treatment with fructose-1,6-diphosphate solution or malate in the presence of $\mathrm{NAD}^{+}$are shown in Table 3. The enzyme activity was determined by the in vitro method. In both cases a higher than in the control NR activity was noted, although the observed increase of NR activity was lower than that observed in stimulation in vitro.

Table 3

Influence of fructose-1,6-diphosphate and of malic acid on in vitro nitrate reductase activity of isolated from Pisum arvense roots

\begin{tabular}{|l|c|c|}
\hline \multicolumn{1}{|c|}{ Substrates } & \multicolumn{2}{|c|}{ Nitrate reductase activity } \\
\cline { 2 - 3 } & nmole $\mathrm{NO}_{\mathbf{2}}^{-} \cdot \mathrm{g}^{-1} \mathrm{fr} . \mathrm{wt}^{\circ} \cdot \mathrm{h}^{-1}$ & $\%$ \\
\hline Control & $37.3 \pm 1.2$ & 100 \\
Fructose-1,6-diphosphate $+\mathrm{NAD}^{*}$ & $55.9 \pm 1.8$ & 150 \\
Malic acid +NAD & $62.2 \pm 2.3$ & 175 \\
\hline
\end{tabular}

Roots cut from the plants were preincubated for $2 \mathrm{~h}$ in phosphate buffer, pH 7.5 containing $\mathrm{KNO}_{3}$ (control samples) and $25 \mu$ moles of the substrates mentioned in the Table. Then enzymic extracts were prepared from these roots and used to nitrate reductase activity determination in vitro. The results are means from five replications. 


\section{DISCUSSION}

The rise of the NR activity level in P. arvense roots incubated in the presence of glucose-6-phosphate, fructose-6-phosphate and fructose-1, 6 -phosphate indicates that $\mathrm{NADH}_{2}$ produced by glycolysis may be a suorce of reducing equivalents for NR. Stimulation of NR by glucose-6-phosphate seems to indicate that in nitrate reduction, $\mathrm{NADPH}_{2}$ the reductor derived from the pentosephosphate pathawy also can be utilised. In the present experiments, however, the ineffectiveness of reduced nucleotide phosphate in the nitrate reduction has been demonstrated, this being manifested by a lack of NR activity stimulation in the presence of $\mathrm{NADPH}_{2}$ (Table 1). Since cell membranes are but poorly permeable to pyridine nucleotides, the foregoing conclusions may arouse certain reservations. The fact, however, that, under identical conditions, addition of $\mathrm{NADH}_{2}$ to the incubation medium as compared with that of the control (Table 1) enhanced NR activity suggests the possibility of penetration of pyridine nucleotides in vivo into the cell.

The high specificity of $\mathrm{NR}$ towards $\mathrm{NADH}_{2}$ as electron donor is a proven fact (Hewitt 1975). Wells and $\mathrm{H}$ a gem a n (1974) actualiy reported the participation of $\mathrm{NADPH}_{2}$ in the process of nitrate reduction, but only in plants containing phosphatases which catalyse the transmition of $\mathrm{NADPH}_{2}$ to $\mathrm{NADH}_{2}$ (spinach, some maize genotypes). In the light of the present results, however, it seems that NR of $P$. arvense roots is specific towards $\mathrm{NADH}_{2}$ as electron donor.

Some metabolites of the Krebs cycle such as 2-oxoglutaric, succinic and malic acids enhanced markedly in $P$. arvense roots the NR activity level measured by the in vivo method. Their effectiveness was noticeable, however, only after 2 -h preincubation of the roots in a solution of the above named acids, but only in the presence of $\mathrm{NAD}^{+}$or $\mathrm{FAD}^{+}$. $\mathrm{A}$ similar result was obtained by measuring in vitro NR activity after preincubation of the roots in malic acid solution with $\mathrm{NAD}^{+}$. Since preincubation of $P$. arvense roots in malic acid and $\mathrm{NAD}^{+}$solution raised the NR activity measured both in vivo and in vitro, it may be supposed that malate influences the enzymatic protein level. This, however, seems but little probable since treatment of roots with a solution of the organic acid alone did not cause changes in NR activity (Table 1). Mann et al. (1978) made similar observations. It is, therefore, more probable that the increased NR activity noted after incubation of roots in organic acid solutions with $\mathrm{NAD}^{+}$may be the result of changes in the amount of reducing equivalents utilised by the enzyme. Thus, enhancement of NR activity observed in the presence of malic acid might be explained by an increase in the cytoplasmic pool of $\mathrm{NADH}_{2}$, owing to oxidation of malic acid by cytoplasmic malate dehydrogenase (Y a mazaki and $\mathrm{T}$ olbert 1969). Such a relation was found in maize leaves (Ney ra 
and $\mathrm{Hageman} 1978$ ) and spinach ( $\mathrm{R}$ athman 1978, Mann et al. 1978, W oo and Canvin 1980). The participation of cytoplasmic malate dehydrogenase in supplying $\mathrm{NADH}_{2}$ for the process of nitrate reduction has also been suggested by Deane-Drummond et al. (1979, 1980) in barley roots.

In the present experiments, however, stimulation of NR activity was observed also in the presence of 2-oxoglutarate and succinate, this suggesting a role of mitochondria of root cells in the supply of reducing equivalents for the process of nitrate reduction. This supposition seems the more probable since malonic acid - a competitive inhibitor of succinate clehydrogenase, one of the enzymes of the Krebs cycle - neutralised the stimulating action of 2-oxoglutaric and succinic acids on NR activity. On the other hand, NR activation noted after preincubation of $P$. arvense roots in malic acid solution was only partly abolished by addition of malonic acid. This fact seems to confirm our supposition that both cytoplasmic and mitrochondrial malate dehydrogenase are involved in supplying reducing power of NR activity.

The action of all the tested organic acids in the present experiments on NR was retarded as compared with that of sugars and appeared as late as after 2-h preincubation of roots in acid solution. This delay may have been due to the different intracellular localisation of the processes of $\mathrm{NADH}_{2}$ production and $\mathrm{NADH}_{2}$-dependent nitrate reduction.

\section{Acknowledgment}

This work was financed from MR II/7 problem.

\section{REFERENCES}

B e evers L., Hageman R. H., 1969. Nitrate reduction in higher plants. Ann. Rev. Plant Physiol. 20: 495-522.

Buczek J., 1976. The role of light in the induction of nitrate reductase and nitrite reductase in cucumber seedlings. Acta Soc. Bot. Pol. 45: 77-92.

Deane-Drummond C. E., Clarkson D. T., Johnson C. B., 1979. The effect of shoot removal and malate on the activity of nitrate reductase assayed in vivo in barley roots (Hordeum vulgare cv. Midas). Plant Physiol. 64: 660-662.

Deane-Drummond C. E., Clarkson D. T., Johnson C. B., 1980. The effect of differential root and shoot temperature on the nitrate reductase activity assayed in vivo and in vitro, in Hordeum vulgare (barley). Relationship with diurnal changes in endogenous malate and sugar. Planta 148: 455-461 .

Hageman R. H., Flesher D., 1960. Nitrate reductase as affected by light and nitrate content of nutrient media. Plant Physiol. 35: 700-708.

Harper J. E., Hageman R. H., 1972. Canopy and seasonal profiles of nitrate reductase in soybeans (Glycine $\max$ L. Marr). Plant Physiol. 49: 146-154. 
Hew it t E. J., 1975. Assimilatory nitrate-nitrite reduction. Ann. Rev. Plant Physiol. 26: 73-100.

J a w orski E. G., 1971. Nitrate reductase assay in intact plant tissues. Biochem. Biophys. Res. Commun. 43: 1274-1279.

Klepper L. A., Flesher D., Hageman R. H., 1971. Generation of reduced nicotinamide adenine dinucleotide for nitrate reduction in green leaves. Plant Physiol. 48: 580-590.

Lips S. H., 1971. Photorespiration and nitrate reduction, In: Proceedings of 2nd International Congress on Photosynthesis. Forti G., Avrgon M., Malandri A. (eds.). The Hague, Junk. pp. 2241-2249.

Mann A. F., Hucklesby D. P., Hewitt E. J., 1978. Source of reducing power for nitrate reductase in spinach leaves. Planta 140: 261-268.

Muld er E. G., Boxma R., Van Veen W. L., 1959. The effect of molybdenum and nitrogen deficiencies on nitrate reduction in plant tissues. Plant and Soil 10: $335-355$.

N e y r a C. A., Hage man R. H., 1978. Pathways for nitrate assimilation in corn (Zea mays L.) leaves. Plant Physiol. 62: 618-621.

$\mathrm{R}$ athman C. K. M., 1978. Malate and dihydroxyacetone phosphate-dependent nitrate reduction in spinach protoplasts. Plant Physiol. 62: 220-223.

Plaut Z., Litton A., 1974. Interaction between photosynthesis $\mathrm{CO}_{2}$ fixation products and nitrate reduction in spinach and wheat leaves. In: Proceedings of 3rd International Congress on Photosynthesis. Avrgon M. (ed.). Elsevier, Amsterdam-London, pp. 1507-1516.

S anderson G. W., Cocking E. C., 1964. Enzymatic assimilation of nitrate in tomato plants. II. Reduction of nitrate to ammonia. Plant Physiol. 39: 423-431.

W o o K. C., Canvin D. T., 1980. The role of malate in nitrate reduction in pinach leaves. Can. J. Botany 58: 517-521.

V e $11 \mathrm{~s}$ G. N., H a g man R. H., 1074. Specificity for nicotinamide adenine dinucleotide by nitrate reductase from leaves. Plant Physiol. 54: 136-141.

Yamazaki R. K., Tolbert N. E., 1969. Ma'ale dehydrogenase in leaf peroxisomes. Biochem. Biophys. Acta 178: 11-20.

Źródła równoważników redukcyjnych redukatazy azotanowej $w$ korzeniach Pisum arvense

\section{Streszczenie}

W pracy podjęto badania nad źródłem reduktora reduktazy azotanowej (E. C 1.6.6.1) $\mathrm{w}$ korzeniach Pisum arvense stosując pomiary in vivo i in vitro aktywności NR. Stwierdzono, że $\mathrm{NADH}_{2}$ wykorzystywany w procesie redukcji azotanów w korzeniach peluszki może pochodzić zarówno z przemian glikolitycznych, jak również z procesów utleniania kwasów organicznych, takich jak kwas $\alpha-k e-$ toglutarowy, bursztynowy i jabłkowy. 